\title{
Performance test of organic planting bags for woody plant seedlings
}

\author{
Musthofa Lutfi ${ }^{1 *}$, Wahyunanto Agung Nugroho ${ }^{1}$, Huy Thanh $\mathrm{Vo}^{2}$, Gunomo Djoyowasito ${ }^{1}$, \\ Ary Mustofa Ahmad ${ }^{1}$, Sandra Sandra ${ }^{1}$ \\ (1. Department of Agricultural Engineering, Faculty of Agricultural Technology, Brawijaya University, Malang 65145, Indonesia; \\ 2. Division of Urban Infrastructural Engineering, Mien Trung University of Civil Engineering, Phu Yen 56000, Vietnam)
}

\begin{abstract}
Organic planting bag has been developed to overcome both weaknesses of plastic polybags, contaminating the soil and damaging the plant's root when transplanting. The improvement in this stage was achieved by inserting coconut fiber to strengthen a bag. The main purpose of this study was to investigate the effectiveness of seedling and transplanting by using organic planting bags, employed, three woody plants, i.e., Albizia (Albizia julibrissin), Cadam (Neolamarckia cadamba) and Gmelina (Gmelina arborea). Performance testing of organic plant bags was conducted on three compositions of coconut fiber and water hyacinth. Two stages of experiments were conducted to know bag performance. First, the testing of organic plant bags during the nursery was conducted for $50 \mathrm{~d}$ from day 0 to day 50 . Second, the testing of organic plant bags after transplanting and observed on days 60,70 , and 80 , after transplanted on the field. The parameters in this study were plant height, a total of roots that penetrate the organic plant bags and a total of leaves and stem diameters of plant grown in the organic bag and transplanting on land. The results showed that organic planting bag with the composition $155 \mathrm{~g}$ of coconut fiber and $505 \mathrm{~g}$ of water hyacinth (A3B3) has $0.020 \mathrm{~kg} / \mathrm{cm}^{2}$ compressive strength and provides the best plant growth rates. Compressive strength affects the number of roots which penetrate the organic bag. Generally, the growth of seed in organic bags is faster than that in polybags. Albizia shows a higher growth rate $(0.379 \mathrm{~cm} / \mathrm{d})$ compared to Cadam and Gmelina.
\end{abstract}

Keywords: seedling effectiveness, organic planting bag, nursery, transplanting, woody plant

DOI: $10.25165 /$ j.ijabe.20201305.4975

Citation: Lutfi M, Agung N W, Vo T H, Djoyowasito G, Ahmad A M, Sandra S. Performance test of organic planting bags for woody plant seedlings. Int J Agric \& Biol Eng, 2020; 13(5): 93-98.

\section{Introduction}

Plant nursery in principle is to manage the source of nursery, location and nursery management ${ }^{[1]}$. One important nursery source is planting media. Farmers often use polybags to plant nursery. Polybag is made from plastic which is cheap, rustproof, durable, mild, uniform shape, and not easily dirty as well as easily obtained $^{[2]}$. Seedbed placed in polybags must be torn before planted in the plant area. The tearing process can damage the roots making the seedlings die after transplanting ${ }^{[3]}$.

Transplanting or replanting is defined as the technique of moving a plant from one location to another. Generally, the process starts with planting from seed in optimal conditions, such as in a greenhouse or protected nursery bed, followed by replanting it in another place, usually outdoor or in growing locations. Transplanting has a variety of applications, including (1) Extending the growing season by starting to plant indoors, which previously outdoor conditions are more favorable; (2) Protecting young plants

Received date: 2019-02-13 Accepted date: 2019-08-02

Biographies: Wahyunanto Agung Nugroho, $\mathrm{PhD}$ candidate, Assistant Professor, research interest: agricultural engineering, Email: wahyunanto@ub.ac.id; Huy Thanh Vo, PhD, Assistant Professor, research interest: environmental engineering, Email: vothanhhuy@muce.edu.vn; Gunomo Djoyowasito, $\mathrm{PhD}$, Associate Professor, research interest: agricultural machinery, Email: djojowasito@ub.ac.id; Ary Musthofa Ahmad, PhD, Assistant Professor, research interest: agricultural engineering, Email: arymustofa@ub.ac.id; Sandra Sandra, PhD, Associate Professor, research interest: food processing and post-harvest technology, Email: sandra.msutan@ub.ac.id.

*Corresponding author: Musthofa Lutfi, $\mathrm{PhD}$, Associate Professor, research interest: agricultural engineering. J1. Veteran Malang, 65145, Indonesia. +62-838-48264197, Email: lutfi@ub.ac.id. from diseases and pests until they are sufficiently established; (3) Avoiding germination problems by setting out seedlings instead of direct seeding planting. The transplanting process affects to root system structure which plays an important role in seedling establishment ${ }^{[4]}$.

Nowadays, many organic polybags have been developed which are used as planting media, such as viz. root trainers container for Indians sandalwood (Santalum album L.) seedlings ${ }^{[6]}$, Black and white biodegradable bags for Brazilian ginseng seedling (Pfaffia glomerata (Spreng) Pedersen) ${ }^{[7]}$, containers made from newspapers, corn starch, palm, cotton, paper, clay and cow dung (Bio-decomposable (Jiffy) Pots) ${ }^{[8]}$, and biodegradable cellulose paper for small-scale tree nurseries ${ }^{[9]}$.

Green et al. ${ }^{[10]}$ describing that nursery treatment promotes advantageous changes in some root structural characteristics. On the other hand, biosolid can be used as a growing medium to maintain substrate status ${ }^{[11]}$ maintaining the organic content to keep the moisture ${ }^{[12]}$. Hence developing the planting bag by using biosolid as a material is promising for the nursery industry. Nursery using organic planting bag assists in root collar planting depth in a good position to improve tree quality after establishment ${ }^{[13]}$. Djoyowasito et al. ${ }^{[14]}$ develop organic planting ribbon (OPR) describing a kind of organic component significantly affecting organic plating bag performance ${ }^{[14-16]}$. As the research of Wataru et al. ${ }^{[17]}$, these observations would be explained by the higher level of water-soluble organic matter and its sorption and decomposition in the soil thereby increasing the incubation time. Finding out that coconut fiber can improve the strength of organic planting bags.

As research results of Weng et al. ${ }^{[18]}$, Bilck et al. ${ }^{[19]}$, Kijchavengkul et al. ${ }^{[20]}$, materials composed of biodegradable 
polyester from renewable or fossil resources, or a combination of both, like Ecobras ${ }^{\mathrm{TM}}$ (BASF, Germany), are being studied as an alternative to substitute the traditional synthetic polymers that are used in agriculture, such as mulch film, bags, low tunnels and greenhouses. These materials are susceptible to various forms of degradation (thermal, oxidative, mechanical, or biological) after being exposed to the environment. Biodegradable plastics base on local commodities have been developing for future alternative material $^{[21-23]}$.

Polyethylene bag grown seedlings have a deformed taproot because seedling roots tend to grow in spirals once they hit the smooth inner surface, this inevitably leads to plants with restricted growth, poor resistance to stress and wind-throw and even early dieback due to ensnarled root masses or pathogens ${ }^{[24,25]}$. Transplanting by using organically plant bags has been done ${ }^{[26]}$ to seasonal plant nursery of cayenne pepper. Another study ${ }^{[27]}$ used organically plant bag for tobacco nursery showed that organically plant bag for plant nursery was better than polybags due to the composition of organic matter. According to reference [28], organic matter is a natural substrate for microorganisms and provides nutrients to plants. Organic matter also influences aggregate distribution and stabilization as well as the movement of groundwater. Vos et al. ${ }^{[2]}$ has proposed three characteristics of bioplastics and/or paper that would render them suitable for use in composting and organic recovery.

Across Indonesia, there are millions of hectares of degraded land in need of rehabilitation. There is a growing interest at both the government and farmer levels of converting some of these lands to be more productive, including growing the trees. Smallholders often practice tree farming to generate income and traditionally cultivate a wide range of tree species in mixed agroforestry systems ${ }^{[30]}$. Forest plants are cultivated in Indonesia because they provide many advantages. The woods are often used for furniture and material building. Indonesian government is currently planting a million trees for forest conservation. Polybag reduction can improve the conservation of forests. Based on that consideration, this study is conducted to test the annual plant growth in organic planting bags. This study tries to develop a type of organic planting bag for woody plants and then compares the performances with plastics polybags in the nursery. There are many types of annual plants that can be cultivated in Indonesia. Each plant has different growth characteristics. Gmelina arborea is easy to cultivate and to grow at the smallholder level. It has been widely grown in plantations in South and Southeast Asia, including Indonesia. Gmelina arborea is one of the broad-leafed plants of the Verbenaceae family which grows fast and does not require high, requirements to attain good growth. Similarly, Albizia is also widely cultivated in Indonesia because of its rapid growth rate compared to other types of annual plants and gives faster economic returns. Albizia tree has a height of about 30$45 \mathrm{~m}$ and the diameter of the trunk is about $70-80 \mathrm{~cm}^{[31]}$. Cadam also has a growth rate similar to Albizia if treated optimally ${ }^{[32]}$.

According to Irwanto ${ }^{[1]}$ annual plant nursery activities were conducted as follows: (1) Making shade at the nursery; (2) Nursery media; (3) Conducting watering plants. The shade was used to protect seedlings from rainwater which can damage the plants. Nursery media have to choose to increase root growth and to keep moisture. The optimal age of seedlings for transplanting annual plants to land is 3 months depending on the seed itself. Seedling of planting activities includes determination of the planting distance and preparation of planting areas and planting seeds in the planting area. Annual plants can have high growth and have dense leaves that require the proper planting distance. Planting seed in the planting area should be conducted with caution to avoid plant roots damage. According to the explanation above, this study aimed at producing organic planting bags as a planting area for the seedling. The developed organic planting bags were tested in the three woody plants such as Albizia, Cadam and Gmelina. The research was to compare the shoot growth rate (root, leaves and basal diameter) of seedlings grown in three composition formers of organic planting bags.

\section{Materials and methods}

The process of making organic planting bags was conducted at the power and agricultural machinery laboratory, Brawijaya University, Malang. Testing of organic plant bag was conducted at Jember, East Java, Indonesia. This study used a ruler to measure the plant height, calipers to measure the diameter of plant stems, polybag plastic as control and nets to shade nursery. Materials used in this study were organic plant bags with three different compositions, water for plants, soil for growing media, seedlings of Albizia, Cadam and Gmelina with the age of 25-30 d as the plants are ready to be tested its growth, manure and fungicides to remove the fungus and to add nutrients to the soil.

Testing of organic plant bags was conducted on 3 comparisons between the composition of coconut coir and water hyacinth, and the compressive strength of different organic plant bags, which consists of A1B1 with $455 \mathrm{~g}$ of water hyacinth, $205 \mathrm{~g}$ of coconut coir and $0.031 \mathrm{~kg} / \mathrm{cm}^{2}$ of compressive strength, A2B2 with $480 \mathrm{~g}$ of water hyacinth, $180 \mathrm{~g}$ of coconut coir and $0.023 \mathrm{~kg} / \mathrm{cm}^{2}$ of compressive strength, A3B3 with $505 \mathrm{~g}$ of water hyacinth, $155 \mathrm{~g}$ of coconut coir and $0.020 \mathrm{~kg} / \mathrm{cm}^{2}$ of compressive strength. Each organic plant was tested for each of three types of plants which were: Albizia (Albizia julibrissin), Cadam (Neolamarckia cadamba) and Gmelina (Gmelina arborea). Plants that have been tested were previously planted in a nursery for 25-30 d. The experiment was conducted in two stages of the testing of organic plant bags during the nursery which was conducted for $50 \mathrm{~d}$ from day 0 to day 50 and the testing of organic plant bags after transplanting in the field which is conducted for $30 \mathrm{~d}$, from day 60 to day 80 . The observation was done every $10 \mathrm{~d}$.

The observations made in this study included the growth of seedlings before the transplanting and after transplanting, the comparison of plant growth with polybags. Parameters in this study were plant height, a total of roots penetrating the organic plant bag, a total of leaves and stem plant diameters.

1) Plant height

Plant height was measured perpendicularly from the main stem which was just above the soil to the growing point using a ruler. Measurements were made on days 10,20,30, 40 and 50 in organic plant bags, and on days 60, 70, 80 after transplanted on the field.

2) Total of roots

Root penetrates of the organic plant bag was measured manually by counting the number of roots stuck to the walls of the planting bag. The observations were made on days 10, 20, 30, 40, 50 when planted in organic plant bags.

\section{3) Total of leaves}

The observations of a total of leaves were necessary because of its function as a means of receiving light and photosynthesis of plants. Measurements were made on days 10, 20, 30, 40 and 50 in organic plant bags, and on days $60,70,80$ after transplanted on the field. 


\section{4) Stem diameters}

Stem diameter was measured using a caliper. The measurement was conducted at the midpoint of the high stand of stems plant. The observations were made on days 10, 20, 30, 40, 50 when the plants were in organic plant bags and on days $60,70,80$ after transplanted on the field.

\section{Results and discussion}

\subsection{Plant height}

The growth of plant height in every observation started from day 0 to day 80 after transplant. Figure 1 shows that the most significant increase in plant height occurred on day 60 after the transplanting process. This was because the plant has a wider space on land, especially space for the roots to absorb nutrients in the soil, and space for the leaves to get enough sunlight for photosynthesis.

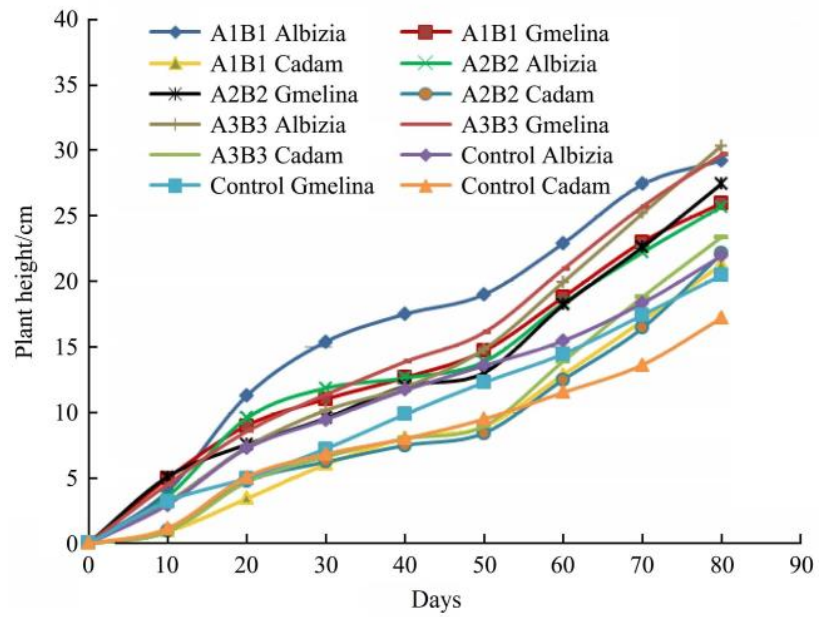

Figure 1 Plant height at different treatments and plants

From Figure 1, it was apparent that plants in polybags resulted in a smaller increase of plant height than that of organic bag treatments. This is because the polybag is made of black plastic material, increasing the temperature of the planting media and soil. Increasing the temperature of the planting medium will inhibit plant growth. According to research conducted by De Lucia et $\mathrm{al}^{[33]}$ at the beginning of the experiment, the percentage in the mixture of planting media can affect significant values of physical and physicochemical properties. Compost has produced an increase in $\mathrm{pH}$ value and electricity conductivity (EC). The value of EC growth media is strongly influenced by the addition of CSS.

The soil organic matter in $0-20 \mathrm{~cm}$ and $20-40 \mathrm{~cm}$ layers increased over the years, while the total nitrogen content declined after initially increasing and peaking at about 5-10. This resulted in a low $\mathrm{C} / \mathrm{N}$ value at about $5-10$. When the $\mathrm{C} / \mathrm{N}$ drops below 25:1, microorganisms no longer utilize available nitrogen in the soil, whereas the soil organic matter is decomposed by microorganisms and then releases mineral nitrogen, thus increasing the available nitrogen in the soil that can be utilized by crops $^{[34]}$. ANOVA indicated that the treatment composition of the organic plant bag was significant $(p<0.05)$ affecting the plant height, but the types of the plant did not affect plant height. The high growth rate of plants can be seen in Table 1.

Table 1 indicates that the growth rate Albizia is greater in plant height than the growth in the other two types of plants. Each plant shows different growth rates. Table 1 also indicates that the treatments affect plant height in the growth rate of the plant of A3B3 treatment which was better than the other three treatments.
This is because the composition of organic plant bags A3B3 has a lower compressive strength test data than in the other organic plant bags $\left(0.020 \mathrm{~kg} / \mathrm{cm}^{2}\right)$. The compressive strength of A3B3 can be considered as the most ideal for plant growth, the low compressive strength indicates it has relatively large pores, where the roots are easy to penetrate the organic planting bag and the roots move freely to get the nutrients from the soil. Meanwhile, the organic plant bag of A1B1 and A2B2 was considered to be too strong as an annual plant nursery media; therefore, the roots of juvenile plants are more difficult to penetrate the plant bag.

Table 1 Growth Rate of Plants

\begin{tabular}{cccc}
\hline \multirow{2}{*}{ Treatments } & \multicolumn{3}{c}{ Growth rate of plants/cm·day } \\
\cline { 2 - 4 } & Albizia & Cadam & Gmelina \\
\hline A1B1 & 0.365 & 0.266 & 0.324 \\
A2B2 & 0.321 & 0.276 & 0.343 \\
A3B3 & 0.379 & 0.292 & 0.371 \\
Control & 0.274 & 0.215 & 0.272 \\
\hline
\end{tabular}

\subsection{Total of roots}

The total roots that penetrate into the organic planting bags at each time of the observation during the plant nurseries. The roots begin to penetrate into the organic plant bags on day 30 because on that day, the plant is able to adapt to new plant media.

Based on Figure 2, it can be seen that treatment A3B3 has the highest total of plant roots penetrating into the organic plant bag, followed by treatment $\mathrm{A} 2 \mathrm{~B} 2$ and $\mathrm{A} 1 \mathrm{~B} 1$. The roots which penetrate the organic plant bags are influenced by the compressive strength of the organic plant bag itself, where bags of planting A3B3 have the lowest compressive strength $\left(0.020 \mathrm{~kg} / \mathrm{cm}^{2}\right)$. The type of plant does not affect the number of roots that penetrate into the organic plant bag. Although Albizia plants have the largest total roots, the overall result was not significant. ANOVA indicates that the treatment composition of organic plant bags has a significant effect $(p<0.05)$ on a total of roots that penetrate into the organic plant bag, but the types of plants do not affect a total of roots. The root is useful to absorb the nutrients in the soil; therefore, it is important to note that the role plant roots against a high accretion of plants. Figure 3 shows the relation of the high plant and total of roots.

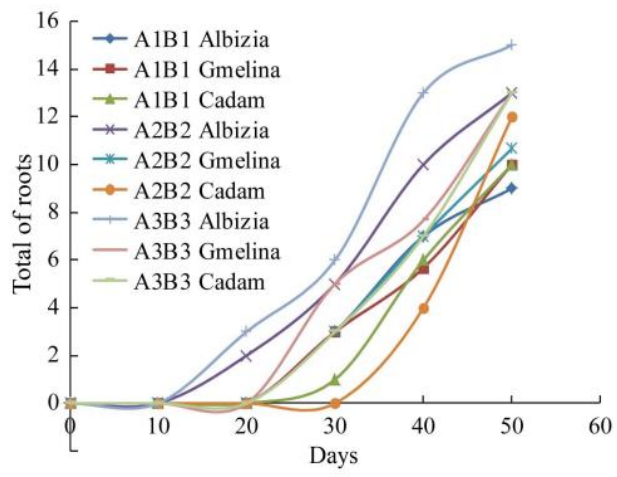

Figure 2 Total of roots penetrating into the organic plant bag

Another research showed that relative water content was highly influenced by salinity levels ${ }^{[35]}$, it was related to the condition of A3B3 bags which had the lowest compressive strength which makes it possible to had low water content that affected to salinity levels. The fresh and dry weight percentage reduction was lower in the shoots than in the roots. Reduction in seedling growth as a result of salt stress has been reported in several other species ${ }^{[36,37]}$. Salinity has both osmotic and specific ionic effects on seedlings ${ }^{[38]}$. 
Figure 3 shows that the relationship is obtained between the total plant roots that penetrate the organic planting bag and the plant height which is positively correlated. The magnitude of the correlation coefficient indicates the number of roots that penetrate into the organic planting bags contributing to $67.2 \%$ against the high growth of plants. This is because the roots absorb nutrients from the soil affecting plant height. As research, the PE bags were complete and lacked any signs of decomposition or tearing, with only a few holes that were caused by root growth and could damage the root condition ${ }^{[7,39]}$ studied the biodegradation of blends of ATp and PEBD in activated mud during a $45 \mathrm{~d}$ period and found that the pure PEBD films did not lose mass, whereas the blends with $32 \%$ and $68 \%$ ATp lost $39 \%$ and $92 \%$ mass, respectively.

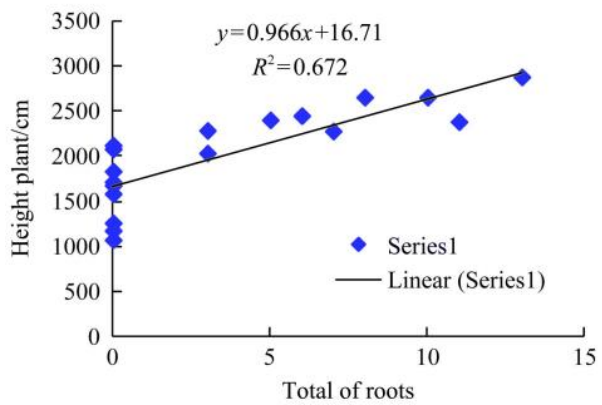

Figure 3 Relation of plants height and total of roots

The ability of root penetration is influenced by the composition of the organic planting bag material made. According to Mattsson $\mathrm{A}^{[5]}$, among different types of containers, the growth of Santalum album L. seedlings was better in black containers (root trainers and plastic containers) than in polybags. Among all the containers, $600 \mathrm{~mL}$ single-cell root trainers resulted in the best growth, followed by $270 \mathrm{~mL}$ block-type root trainers. Block-type root trainers are easier to handle, manage and transport than single-cell root trainers.

\subsection{Total of leaves}

Leaves play an important role in plant growth due to the leave function in the plant organ to do photosynthesis. Figure 4 shows the relation of the height plants and the total of leaves.

The correlation coefficient in Figure 4 indicates that the total of leaves contributes to $77 \%$ against the high growth of plants. This is because the leaf is a part of the plant to conduct photosynthesis, whose results will be transferred to all parts of the plant, thus, the more number of leaves, the process of photosynthesis and plant growth will be good.

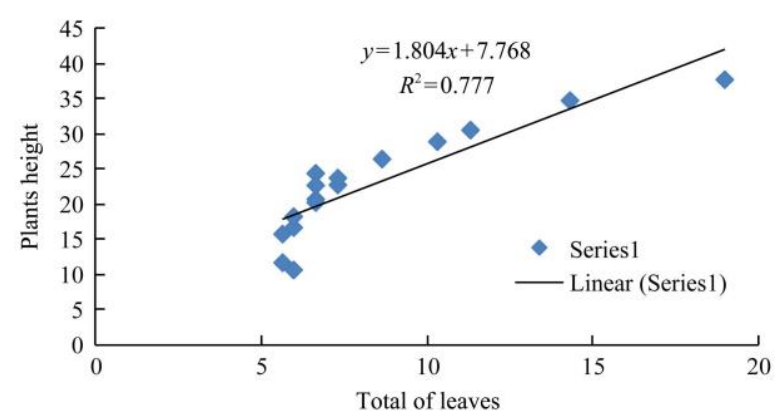

Figure 4 Relation of plants height and total of leaves

According to Muriuki et al. ${ }^{[40]}$, the cellulose papers gave room for the roots to access the substrate beyond their walls without strain, implying that delay in decomposition had a little adverse effect on seedling establishment in the field, no roots damage, and certainly can increase of leaves growth.

\subsection{Stem diameters}

Stem diameter is an indicator of plant growth. Figure 5 shows measurements of stem diameters at different treatments and types of plants.

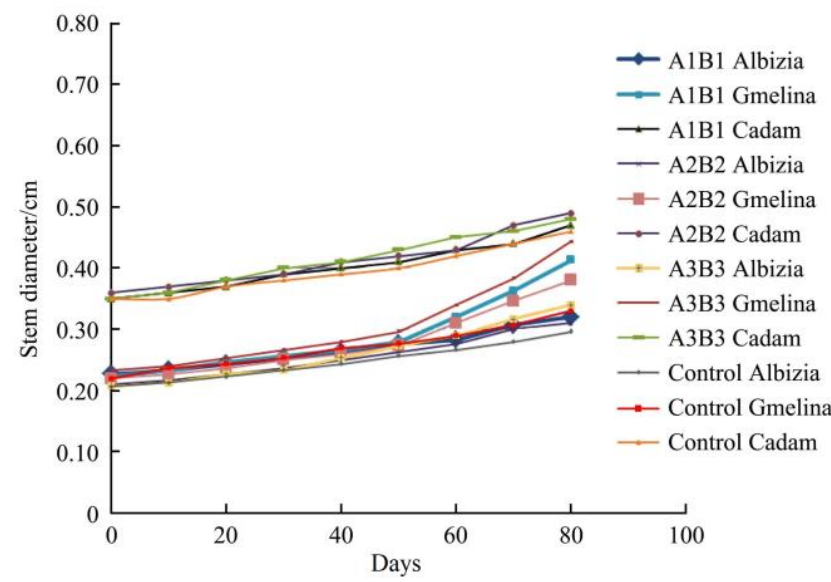

Figure 5 Stem diameters at different treatments and plants

From Figure 5, the diameter of the stem plants during the experiment only a small increase. This is due to the types of annual plants, especially stem growth taking a long time making the difference in diameter at each very short observation time. Generally, cutting of annual plant is conducted to produce a larger diameter stem. Based on Figure 5, it is apparent that there is an insignificant effect of treatment in diameter. Although Cadam plant has a larger diameter than the other plants, ANOVA indicates that the treatment composition of organic plant bags has an insignificant effect $(p>0.05)$ on stems diameter plants but the types of plants affect plant stem diameter.

\subsection{Best treatment}

The determination of the best treatment is based on the results of measurements of each parameter. The results of this study show that A3B3 composition is the best treatment for woody plant nursery media. A3B3 composition has compressive strength which is smaller than the other compositions. The compressive strength of organic plant bags affects the total of roots which penetrate the organic bags. Indicator of plant growth is easily observed from the height of plants, total of roots and total of leaves.

The leaf becomes a vital part of the plant to conduct photosynthesis, whose results will be transferred to all parts of the plant. Thus, the more number of leaves, the process of photosynthesis and height plant growth will be better. Plants obtain nutrients from the soil through the root therefore, the more roots penetrating into the organic plant bag, the plants grow. On the other hand, a lower compressive strength of organic planting bags will make roots easier to penetrate and to reach out from it. The composition of A3B3 with the compressive strength of $0.020 \mathrm{~kg} / \mathrm{cm}^{2}$ is the best in terms of both bag strength and root penetration for the woody plants' nursery media.

In addition to the physical parameters of organic planting bag, as compressive ability, the growth of this plant is also influenced by the biological parameters of the organic planting bag itself which is organic material. It is explained by ${ }^{[41]}$ that the results of the PAS 100 bioassay showed that composts derived from the composters containing whole packaging units (starch, paper and PLA) and from the controls gave equal or higher seed germination rates and equivalent or better fresh seedling weights compared with the growth medium base alone. Biodegradable packaging materials exhibited a wide range of biodegradation properties in 
this simulated home composting system run under non-thermophilic conditions (a regime where mesophilic micro-organisms dominate). Zhang et al. ${ }^{[42]}$ reported the mechanical properties of the biodegradable film decreased rapidly after it came into contact with soil. The ridge-top film was in good contact with the soil surface, which accelerated the erosion by soil micro-organisms of the film. Therefore the organic material becomes fertilizer for woody plants.

\section{Conclusions}

Morphological plant attributes such as leaves, roots and trunk height in A3B3 treatment of Albizia are the best for survival after being planted. However, the stem diameter of Gmelina is the biggest one. The treatment composition of A3B 3 is considered as the best composition planting bag consisting of $505 \mathrm{~g}$ of hyacinth water and $155 \mathrm{~g}$ of coconut fiber. It has a compressive strength of $0.020 \mathrm{~kg} / \mathrm{cm}^{2}$, the best composition in terms of both bag strength and root penetration for the woody plants. The performance of woody plants seedling by using organic planting bags is better than using plastic polybags mainly due to plant susceptibility to transplanting stress. The tearing process in plastic polybags is required to induce the plant. In contrast, using organic planting bags promotes a quick adaptation because the tearing process is not required.

\section{Acknowledgements}

The authors acknowledge that this work was supported by the Department of Agricultural Engineering, Brawijaya University for laboratory facilities as well as the International Scientific Publication Office of Brawijaya University for helpful comments to improve this paper.

\section{[References]}

[1] Irwanto Cultivation of forestry. irwantoshut.com. Access on [2017-08-29]

Available: http://www.

[2] Sarpian T. Planting of cayenne pepper in polybags. Jakarta: PT. Penebar Swadaya, 2001; 55p.

[3] Maryani N. The effect of composition of dry weight material and method of mold release on bag organic matter of waste sugar factory. Brawijaya University, Agricultural Engineering Department, Faculty of Agricultural Technology. Rep., 1998; 97p.

[4] Lloret F, Casanovas C, Penuelas J. Seedling survival of Mediterranean shrubland species in relation to root: Shoot ratio, seed size and water and nitrogen use. Functional Ecology, 2002; 13(2): 210-216.

[5] Mattsson A. Predicting field performance using seedling quality assessment. New Forests, 1997; 13: 227-252.

[6] Annapurna D, Rathore T S, Joshi G. Effect of container type and size on the growth and quality of seedlings of Indian sandalwood (santalum album L.). Australian Forestry, 2004; 67(2): 82-87.

[7] Bilck A P, Olivato J B, Yamashita F. Biodegradable bags for the production of plant seedlings. Polímeros, 2014; 24(5): 547-553.

[8] Khan A A, Mahmood T, Bilqees B. Development of bio-decomposable (jiffy) pots for raising and transplanting nursery plants. Int J Agric \& Biol, 2002; 2(4): 380-381.

[9] Muriuki J K, Kuria A W, Muthuri C W, Mukuralinda A, Simons A J, Jamnadass $\mathrm{R} \mathrm{H}$. Testing biodegradable seedling containers as an alternative for polythene tubes in tropical small-scale tree nurseries. Small-scale Forestry, 2013; 13(2): 127-142.

[10] Green J J, Baddeley J A, Cortina J, Watson C A. Root development in the Mediterranean shrub pistacia lentiscus as affected by nursery treatments. Arid Environments, 2005; 61(1): 1-12.

[11] Apaolaza L H, Gasco A M, Gasco J M, Guerreo F. Reuse of waste materials as growing media for ornamental plants. Bioresource Technology, 2005; 96(1): 125-131.

[12] Rhoades C C, Brosi S L, Dattilo S L, Vincelli P. Effect of soil compaction and moisture on incidence of Phytophthora root rot on
American chestnut (Castanea dentata) seedlings. Forest Ecology and Management, 2003; 184(1-3): 47-54.

[13] Bryan D L, Arnold M A, Volder A, Watson W T, Lombardini L, Sloan J J, et al. Planting depth and soil amendments affect growth of Quercus virginiana Mill. Urban Forestry \& Urban Greening, 2011; 10(2): 127-132.

[14] Djoyowasito G, Utomo W H, Suharto B, Basuki N. Water use efficiency of rice (Oriza sativa L) planted with organic planting ribbon (OPR) in direct seeding system. American-Eurasian Journal of Sustainable Agriculture, 2014; 8(5): 99-104.

[15] Nugroho W A, Rahayu F D, Lutfi M. Effect of ingredients formulation of mechanics traits on organic planting bag. Journal of Agricultural Technology, 2013; 14(2): 115-122

[16] Damar W P. Studying the effect of long fiber coconut fiber and viscosity slurry WH against physical and chemical properties of organic plant pockets on moulds flocking. Bachelor Thesis, University of Brawijaya, Agricultural Engineering Department, Agricultural Technology Faculty, Unpublished. Malang, 2006; 101p.

[17] Masahiko Katoh, Wataru Kitahara, Takeshi Sato. Role of inorganic and organic fractions in animal manure compost in lead immobilization and microbial activity in soil. Applied and Environmental Soil Science 2016; (2016): 7872947. doi: 10.1155/2016/7872947

[18] Weng Y X, Jin Y J, Meng Q Y, Wang L, Zhang M, Wang Y Z Biodegradation behavior of (PBAT), (PLA), and their blend under soil conditions. Polym. Test, 2013; 32 (5): 918-926.

[19] Bilck A P, Grossmann M V E, Yamashita F. Biodegradable mulch film for strawberry production. Polym. Test, 2010; 29: 471. doi: 10.1016/j. polymertesting.2010.02.007.

[20] Kijchavengkul T, Auras R, Rubino M, Alvarado E, Monteiro J R C, Rosales J M. Polym. Degrad. Stab., 2010 95: 99. doi: 10.1016/j. polymdegradstab.2009.11.048.

[21] Lutfi M, Sumarlan S.H., Susilo B., Wignyanto. The glycerol effect on mechanical behaviour of biodegradable plastic from the walur (Amorphophallus paenifolius Var. sylvestris). Natural Environment and Pollution Technology, 2017; 16(4): 1121-1124

[22] Lutfi M, Sumarlan S H, Susilo B, Wignyanto. Mechanical characteristics of biodegradable plastic using elephant foot yam (Amorphophallus paenifolius Var. hortensis) and glycerol. Trends in Carbohydrate Research, 2016; 8(3): 47-51.

[23] Lailyningtyas D I., Lutfi M, Ahmad A M. Mechanical test of bioplastics made from canna edulis starch with variations of cellulose acetate and sorbitol. Journal Keteknikan Pertanian Tropis dan Biosystem, 2020; 8(1): 91-100.

[24] Jones N. Essentials of good planting stock. Forests and Forestry Technical Bulletin Number 2". Washington DC, 1993; 22p.

[25] Jaenicke H, Hince B, Ressler P, Kariuki N, Nether lands G O, Beniest J, et al. Good tree nursery practices: Practical ecoforms guidelines for research nurseries. ICRAF, Nairobe. Kenya, 1999; 94p.

[26] Edwin D C, Eduardo O M, Nestor O G, Arturo E P, John F H. Nursery management in relation to root deformation, sowing and shading. Annals of Tropical Jopski, 2005; 27(1): 1-10.

[27] Hapsari W H. Effect of size fraction of coconut fibers and concentration on bags mixed cropping organic materials (basics made from wate hyacinth) on the growth of cayenne pepper (capsicum frutescent) materials and chemical properties. MS dissertation. Malang: University of Brawijaya, 2006; 91p.

[28] Putra K N. Test of organic plant bag to tobacco plants nursery. MS Dissertation. Malang: University of Brawijaya, 2005; 176p.

[29] Vos Janny G M. Chili integrated crop management (capsium spp.) in the lowland tropics. Wageningen: Wageningen Agricultural University, 1994; 188p.

[30] Wilde B D, Boelens J. Prerequisites for biodegradable plastic materials for acceptance in real-life composting plants and technical aspects. Polymer Degradation and Stability, 1998; 59(1-3): 7-12.

[31] Roshetko J M, Mulawarman, Purnomosidhi P. Gmelina arborea-a viable species for smallholder tree farming in Indonesia? New Forests, 2004 28(2): 207-215.

[32] Santoso B. Albizia cultivation, Yogyakarta: Kanisius, 1997; 50p

[33] De Lucia B, Cristiano G, Vecchietti L, Rea E, Russo G. Nursery growing media: Agronomic and environmental quality assessment of sewage sludge-based compost. Applied and Environmental Soil Science, 2013; 10: $205-214$

[34] Hartanto H. Cultivation patterns of Cadam. Yogyakarta: Brilliant Books, 2011; 108p. 
[35] Li J, Xu Y, Liu H G. Variations of soil quality from continuously planting greenhouses in North China. Int J Agric \& Biol Eng, 2019; 12(1) 139-145.

[36] Vibhuti, Shahi C, Bargali K, Bargali S S. Seed germination and seedling growth parameters of rice (Oryza sativa $\mathrm{L}$.) varieties as affected by salt and water stress. Indian Journal of Agricultural Sciences, 2015; 85(1): 102-108.

[37] Kabir A, Achakzai K, Kayani S A, Hanif A. Effect of salinity on uptake of micronutrients in sunflower at early growth stage. Pakistan Journal of Botany, 2010; 42(1): 129-139.

[38] Akram M, Ashraf M Y, Ahmad R, Waraich E A, Iqbal J, Mohsan M. Screening for salt tolerance in maize (Zea mays L.) hybrids at an early stage. Pakistan Journal of Botany, 2010; 42: 141-151.

[39] Dioniso-Sese M L, Tobita S. Effects of salinity on sodium content and photosynthetic responses of rice seedlings differing in salt tolerance. Journal of Plant Physiology, 2000; 157(1): 54-58.

[40] Muriuki J K, Kuria A W, Muthuri C W, Mukuralinda A, Simons A J, Jamnadass $\mathrm{R}$ H. Testing biodegradable seedling containers as an alternative for polythene tubes in tropical small-scale tree nurseries. Small-scale Forestry, 2013; 13: 127-142.

[41] Tena-Salcido C S, Rodríguez-González F J, MéndezHernández M L, Contreras-Esquivel J C. Polym Bull, 2008; 60: 677. doi: 10.1007/s00289-008-0903- 13.

[42] Zhang W W, Wang L H, Zhou J Q, Zhu K L, Sun S J. Degradability of biodegradable plastic films and its mulching effects on soil temperature and maize yield in northeastern China. Int J Agric \& Biol Eng, 2020; 13(2): $146-153$. 